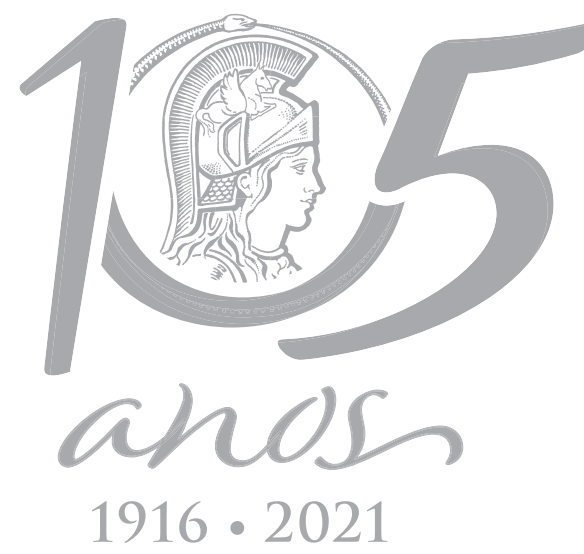

\title{
The addition of green propolis to laying hens had positive effects on egg quality: lower bacteria counts in the shell and lipid peroxidation in the yolk
}

\author{
ANA CLAUDIA CASAGRANDE, GIOVANA C. MACHADO, ANDREI L. BRUNETTO, \\ GABRIELA M. GALLI, GILNEIA DA ROSA, DENISE N. ARAUJO, MARCEL M. BOIAGO, \\ CARINE F. SOUZA, MATHEUS M. BALDISSERA \& ALEKSANDRO S. DA SILVA
}

\begin{abstract}
This study aimed to determine whether the addition of green propolis extract to the diet of laying hens would improve egg quality and bird performance and decrease bacterial contamination of eggs. Forty-five brown Hy-line laying hens were used, divided into five groups with three replicates each and three animals per cage: T0 - diet without propolis; T5 - 5 grams of propolis per kg of feed; T10 - 10 grams of propolis per kg of feed; T20 - 20 grams of propolis per $\mathrm{kg}$ of feed and T30 - 30 grams of propolis per $\mathrm{kg}$ of feed. The quality of fresh eggs was made on day 21 of the experiment, and eggs were stored for 21 days. Greater specific gravity was observed in fresh eggs in T5 birds and stored eggs for T10. TBARS in fresh eggs, we found that T30 eggs had lower levels compared to other treatments. T20 eggs had the lowest total bacterial count and the lowest total coliform count in the eggshells of T10 and T20 chickens. The count of E. coli in the peel was lower for T20 and T30 than T0 and T5. The consumption of propolis did not interfere with the hens' egg production rate but reduced food intake and consequently reduced feed conversion. We concluded that the addition of green propolis in the diet of laying birds proved efficient in reducing bacterial contamination in the eggshells and reducing the lipid peroxidation of fresh and stored eggs.
\end{abstract}

Key words: antioxidants, antimicrobial action, oxidations, propolis.

\section{INTRODUCTION}

The demand for eggs with quality and safety certifications has grown, primarily due to their high nutritional value, which contributes to the growth of laying poultry. Brazil is the fifth-largest world producer of eggs (Procópio \& Lima 2020); also, it is the fifth most-consumed protein in the world. In 2019, Brazil produced around four billion dozens, of which $99.59 \%$ remained on the domestic market (ABPA 2019), with an increase in per capita egg consumption from 148 in 2010 to 230 in 2019 (ABPA 2020).
Eggs are considered foods of the highest nutritional value, as they are an excellent source of fatty acids, vitamins, minerals, and essential amino acids (Mendonça et al. 2019). However, how eggs are preserved, the composition of the diet provided to birds, and storage at room temperature, influence the internal quality of this product, as they directly affect the lipid stability of the yolk (Ding et al. 2017), as well as high temperatures, cause oxidation (Zhu et al. 2015). However, in addition to changes that may involve the physical-chemical integrity of eggs, 
microbiological problems can also affect this product and pose a threat to human health.

In this context, eggs are liable to be contaminated by bacteria, such as Salmonella spp. and Escherichia coli, in the bark externally by the environment (Gantois et al. 2009), or internally by a vertical transmission in which the bacteria infect the bird's oviduct and starts to contaminate yolk, albumen, bark membranes, even before of posture (Gast et al. 2013). In this way, the use of phytogenic additives in the laying diet can provide a better physical, chemical, and biological quality of fresh and stored eggs without compromising these animals' performance (Santos et al. 2005, Valentim et al. 2018). They can also improve the palatability of the feed, stimulate the immune system, and have anti-inflammatory, antioxidant, and antimicrobial activity (Garcés et al. 2018).

Supplementation with apicultural origin substances appears alternative in animal nutrition due to their therapeutic and prophylactic properties, with great emphasis on propolis, which has anti-inflammatory, antioxidant, immunomodulatory, analgesic, antibacterial, and antiviral activity (Genova et al. 2020). The addition of propolis to the broiler diet can stimulate the immune system and improve animal performance (Cardozo et al. 2013). Because it does not present residues, it becomes a safe additive for animal production. Thus, this study's objective was to evaluate whether the addition of green propolis extract to the laying hens' diet can improve animal performance, egg quality, and reduce bacterial contamination in the egg.

\section{MATERIALS AND METHODS}

\section{Propolis}

In this study, green propolis was purchased from a company located in the Chapecó region, Santa
Catarina, Brazil. Propolis analysis was previously published when provided in the lamb diet, where it was recorded that the concentration of total phenolic compounds was $916.28 \pm 23.22$ $\mathrm{mg}$ equivalent in gallic acid/mL; the antioxidant activity $\left(I C_{50}\right)$ was $158.15 \pm 4.47 \mu \mathrm{g} / \mathrm{mL}$; and the propolis extract had concentrations of gallic acid of $0.57 \mathrm{mg} / \mathrm{mL}$, p-coumaric acid of $3.10 \mathrm{mg} /$ $\mathrm{mL}$, and chlorogenic acid of $1.41 \mathrm{mg} / \mathrm{mL}$ (Cecere et al. 2021).

Propolis did not replace any dietary ingredient, it was an additive, that is, an extra product in the diet of hens.

\section{Experimental design}

This study was approved by the Committee on Ethics of Animal Welfare (CEUA) of the State University of Santa Catarina (UDESC). The experiment was conducted in the experimental shed at the State University of Santa Catarina-UDESC, located in Chapecó, Brazil. The experimental design was completely randomized, and each repetition was considered an experimental unit. The experimental period was 21 days, which corresponded to a productive cycle. Forty-five brown Hy-line laying hens, 100 weeks old, were placed in cages and divided into five groups with three replicates each, in which three animals were distributed per cage. Water and feed were ad libitum. According to the Brazilian Tables' nutritional requirements for Poultry and Swine, the light program used natural and artificial light, which totaled 16 hours of light and eight hours of darkness, according to the Brazilian Tables' nutritional requirements for Poultry and Swine (Rostagno et al. 2017, Table I). To stipulate consumption, the lineage manual was used, being calculated $120 \mathrm{~g} /$ chicken/day. All groups received the same basal diet. What changed was the addition or not of propolis. The experimental design was as follows: Group T0 birds that received only a basal diet, that is, 
Table I. Composition of the experimental diets: ingredients, and calculated composition.

\begin{tabular}{|c|c|}
\hline Ingredients & $\mathrm{g} / \mathrm{kg}$ of natural matter \\
\hline Corn & 667.72 \\
\hline Soybean meal & 199.53 \\
\hline Methionine & 3.10 \\
\hline Lysine & 1.30 \\
\hline Threonine & 0.70 \\
\hline Tryptophan & 0.15 \\
\hline Limestone & 91.00 \\
\hline Soybean oil & 15.01 \\
\hline Dicalcium phosphate & 13.02 \\
\hline Premix $^{*}$ & 3.00 \\
\hline Common salt & 1.58 \\
\hline Bicarbonate & 3.90 \\
\hline \multicolumn{2}{|l|}{ Calculated composition } \\
\hline Crude protein $(\mathrm{g} / \mathrm{kg})$ & 146.65 \\
\hline Metabolizable energy (Kcal/kg) & 2894 \\
\hline Calcium $(\mathrm{g} / \mathrm{kg})$ & 38.94 \\
\hline Sodium (g/kg) & 1.79 \\
\hline Chlorine (g/kg) & 1.64 \\
\hline Total phosphorus (g/kg) & 5.11 \\
\hline Disponible phosphorus (g/kg) & 3.19 \\
\hline Lysine $(\mathrm{g} / \mathrm{kg})$ & 7.35 \\
\hline Methionine + cysteine (g/kg) & 7.24 \\
\hline Tryptophan $(\mathrm{g} / \mathrm{kg})$ & 1.68 \\
\hline Threonine (g/kg) & 5.68 \\
\hline
\end{tabular}

Note: Propolis did not replace any dietary ingredient, it was an additive, that is, an extra product in the diet of hens.

*Product composition (kg): Vitamin A at 7,000,000 IU; Vitamin D3 at 4,000,000 IU; Vitamin E at $5000 \mathrm{mg}$; Vitamin K at $1200 \mathrm{mg}$; Vitamin B1 at 360 mg; Vitamin B2 at 2000 mg; Vitamin B6 at 700 mg; Vitamin B12 at 7000 mcg; niacin 7500 mg; biotin 30 mg; pantothenic acid $6000 \mathrm{mg}$; folic acid $300 \mathrm{mg}$; iron 11000 mg; copper 3000 mg; iodine 204 mg; chlorine 360 mg; coccidiostatic 100 g; antifungal $2000 \mathrm{mg}$; antioxidant $10 \mathrm{mg}$; magnesium 50 g; sulfur 40 g; energy and protein vehicle (q. s. p.) 1,000 g.

without propolis; group T5 birds that received 5 grams of propolis per $\mathrm{kg}$ of feed; T10 birds that received 10 grams of propolis per $\mathrm{kg}$ of feed; $T 20$ birds that received 20 grams of propolis per $\mathrm{kg}$ of feed and $T 30$ birds that received 30 grams of propolis per $\mathrm{kg}$ of feed.

\section{Animal performance}

Egg production (\%): Daily, the eggs of each repetition were collected and counted. Thus, in the end, it was possible to calculate egg production (\%). For the egg mass variable ( $\mathrm{g} /$ bird/day): The eggs were identified and weighed individually for three consecutive days. Based on these data, the egg mass was obtained by the following formula: Egg mass = average weight ( $\mathrm{g}$ ) $x$ percentage of egg production (\%). As for feed consumption (g/bird/day): The rations were weighed at the beginning and at the end of the experiment to assess consumption.

Feed conversion ( $\mathrm{kg} / \mathrm{kg}$ and $\mathrm{kg} / \mathrm{dozen})$ : Feed the average feed consumption obtained conversion $(A C)$ per $\mathrm{kg}$ of the egg in the experimental period divided by the egg mass, 
that is, the amount of feed consumed to produce a kilogram of eggs. To calculate the feed conversion per dozen eggs produced, the amount of food consumed in the period was divided by the number of eggs produced multiplied by 12 .

\section{Analysis of egg quality}

To evaluate the eggs' quality, a sample made up of two eggs per repetition of each group was collected on the 21st and processed on the same day (fresh eggs). Two eggs per repetition of each group were collected on day 20 and stored in a temperature-controlled place (25 $\pm 2{ }^{\circ} \mathrm{C}$ ) for 21 days. The following parameters were determined for both fresh and stored eggs: the eggs were weighed in air and water, with the value obtained, the specific gravity was calculated according to the method of Freitas et al. (2004). Eggshell strength (kgf) was measured using a Texture Analyzer (TA. XT plus) coupled to a specific eggshell test (SMS P75) adjusted with a pre-test speed of $5.0 \mathrm{~mm} / \mathrm{s}$; test speed $1.0 \mathrm{~mm} / \mathrm{s}$, and post-test speed $20 \mathrm{~mm} / \mathrm{s}$, which registered the force required to break the shell. After determining the albumen height $(\mathrm{H})$ with an adapted micrometer and egg weight (W), the Haugh unit ( $\mathrm{HU}$ ) was calculated using the equation: $\mathrm{HU}=100 \log (\mathrm{H}(\mathrm{mm})+7.57-1.7 \mathrm{~W}$ (0.37 $\mathrm{g})$, according to the technique described by Haugh (1937).

The yolk index ( $\mathrm{YI}$ ) was estimated with the aid of an adapted micrometer with a relation between the height $(\mathrm{mm})$ and diameter of the yolk $(\mathrm{mm})$. The color of the yolk was estimated using a colorimetric matrix (DSM-Yolk Color Fan ${ }^{\circledR}$ ) and a colorimeter (Minolta CR-400), which determined the luminosity $\left(L^{*}\right)$, red intensity $\left(a^{*}\right)$, and intensity of yellow $\left(b^{*}\right)$. The shells were washed and dried at room temperature to analyze shell thickness with a digital caliper's aid. The results were expressed as the average of the three-point measurement on the egg (apical, basal, and equatorial). Weighing of the shell, yolks, and albumen was performed to calculate the shell, yolk, and albumen percentage concerning the egg weight. The $\mathrm{pH}$ of the yolk and albumen were obtained using a digital pH meter (Texto-2005).

Lipid peroxidation was determined according to the methodology described by Giampietro et al. (2008), which measured substances reactive to thiobarbituric acid (TBARS) in the egg yolk. The decomposition of lipid peroxides was measured using a spectrophotometer (532 nm) and 1,1,3,3 tetramethoxyprop (TMP) as standard. The results were expressed in $\mathrm{mg}$ TPM/ $\mathrm{kg}$ of yolk. The total antioxidant capacity (TAC) was evaluated as described by Erel (2004) after some changes concerning the reaction time and wavelength. TAC levels were measured on a BS 380 automated Mindray ${ }^{\circledR}$ (Shenzhen, China), and the results were expressed as $\mu$ mol Trolox equivalent $\mathrm{t}^{-1} \mathrm{~g}$.

\section{Bacterial counts in eggs}

Egg samples ( $n=6$; two eggs per repeat), collected on day 22 to perform total bacterial counts (CBT) using counting agar plates, as described by Parisi et al. (2015). E. coli and total coliform counts were quantified using $3 \mathrm{M}$ Petrifilm EC plates. Whole shelled eggs were analyzed without cleaning. Whole shells were broken, and the internal contents were discarded. The shells were placed in sterile beakers, ground, and homogenized with a sterile glass stick. One gram of shell was diluted in $9 \mathrm{ml}$ of buffered water solution with $10^{-1}$ dilution for eggs. Then, 1 $\mathrm{ml}$ of the $10^{-1}$ dilution (eggs) of each sample was inoculated into 3M Petrifilm plates for six TBC, and E. coli (EC) and $100 \mu \mathrm{L}$ were inoculated into counting agar plates, followed by incubation for 2448 hours at $37^{\circ} \mathrm{C}$. The results were expressed as colony-forming units per $g$ (CFU/g). 


\section{Blood collection}

Blood collection was performed on three animals per repetition, which totaled six animals per treatment, in two moments: the beginning of the experiment (day 0 ) and the end of the cycle (day 21 of the experiment). The animals were contained manually and using an insulin syringe; blood was collected from the ulnar vein. The blood was stored in tubes without anticoagulant to obtain the serum after centrifugation (3500 rpm for $10 \mathrm{~min}$ ) and stored at $-20 \stackrel{\circ}{ } \mathrm{C}$ until analysis.

\section{Biochemical analyses}

The serum levels of triglycerides, cholesterol, uric acid, total protein, and albumin were measured using commercial colorimetric kits (Analisa ${ }^{\circledR}$ ) in the semi-automatic BioPlus $2000^{\circledR}$ equipment. Globulin levels were obtained using the mathematical formula: total protein - albumin.

\section{Statistical analysis}

The data were submitted to descriptive analysis, followed by the normality test by ShapiroWilk. The data without normal distribution (biochemical variables) were logged. The data were submitted to analysis of variance followed by the Tukey test. It was considered significant when $\mathrm{P}<0.05$.

\section{RESULTS}

For specific gravity, a difference was observed for fresh eggs in which the T5 treatment was superior concerning the others $(P<0.001)$. For the specific gravity of the stored eggs, the treatment T10 was higher $(P<0.017)$, while T20 was higher than the groups T5 and T30 ( $\mathrm{P}<$ 0.017; Table II). For red intensity in both fresh and stored eggs, it was found that treatments
T10, T20, and T30 were superior to treatments T5 and T0 ( $P<0.001$; Table II).

As for the albumen $\mathrm{pH}$, a statistical difference was found for fresh eggs, in which the treatments T5 and T10 were superior to T20 and T30 ( $P<0.001 ;$ Table II). As for \% for the yolk, fresh eggs from T30 showed a higher value compared to treatment T5 $(P<0.050)$. As for the stored eggs, a difference was observed for the \% of the shell, in which T5 was lower than T0, T20, and T30 ( $P<0.001 ;$ Table II).

The T30 treatment showed the lowest levels of TBARS in fresh eggs compared to T0, T5, and T20 $(P<0.001)$. Meanwhile, in stored eggs, T30 was lower than T10 $(P<0.010)$. ACAP in fresh eggs T10 and T20 were superior to T0 and T5 (P $<0.001)$. For the total bacterial count (TBC), T20 had a lower count than the other treatments ( $P$ $<0.001)$. The treatments T10 and T20 had a lower total coliform count (TC) compared to the rest of the treatments $(P<0.001)$. For the count of E. coli in the peel, the T20 treatment had the lowest count to the T0, T5, and T10 ( $<<0.001$; Table II). No differences were observed regarding shell resistance, luminosity (L), yellow intensity (b), shell thickness, yolk pH and albumen (stored eggs), YI, yolk percentage, albumen, and shell ( $P$ > 0.05; Table II).

For biochemical parameters, there was no difference between groups for albumin and uric acid. However, total protein levels at 21 days decreased in all treatments than T0 $(P<0.001)$. Triglyceride levels at 21 days were lower at T5 compared to other treatments $(P<0.001)$. At 21 days at T5 and T20, cholesterol levels were lower than the others $(P<0.010)$. For globulins at 21 days, all treatments decreased to T0 $(P<0.001$; Table III).

Feed intake g/chicken/day in treatments T5, T10, T20, and T30 were lower than T0 ( $P<$ 0.001). As for the feed conversion $\mathrm{kg} / \mathrm{kg}$ of eggs, T5 showed lower conversion than the other 
Table II. Egg quality of fresh eggs (days 21) and stocked eggs by 21 days from laying hens fed with differing propolis levels.

\begin{tabular}{|c|c|c|c|c|c|c|c|c|}
\hline Variable & Eggs & TO & T5 & $\mathrm{T} 10$ & $\mathrm{~T} 20$ & T30 & P-value & $\mathrm{CV}(\%)$ \\
\hline \multirow{2}{*}{ Calculated gravity } & Fresh & $1.091^{b}$ & $1.343^{\mathrm{a}}$ & $1.093^{b}$ & $1.098^{b}$ & $1.044^{\mathrm{c}}$ & 0.001 & 1.41 \\
\hline & Stocked & $1.004^{\mathrm{c}}$ & $1.009^{c}$ & $1.029^{\mathrm{a}}$ & $1.019^{b}$ & $1.004^{\mathrm{c}}$ & 0.017 & 0.98 \\
\hline \multirow{2}{*}{ Bark resistance } & Fresh & 3719 & 3779 & 3576 & 4045 & 3930 & 0.210 & 25.4 \\
\hline & Stocked & 4734 & 3021 & 4027 & 4021 & 3595 & 0.064 & 30.7 \\
\hline \multirow{2}{*}{ Color (sub) } & Fresh & 6.5 & 7.0 & 6.25 & 6.5 & 6.25 & 0.745 & 2.74 \\
\hline & Stocked & 6.25 & 6.25 & 6.50 & 5.95 & 6.25 & 0.398 & 4.62 \\
\hline \multirow{2}{*}{$L$} & Fresh & 59.7 & 56.1 & 57.2 & 60.1 & 60.6 & 0.541 & 6.41 \\
\hline & Stocked & 49.9 & 53.0 & 56.6 & 53.7 & 50.3 & 0.056 & 7.04 \\
\hline \multirow{2}{*}{ A } & Fresh & $-5.62^{b}$ & $-5.50^{b}$ & $-6.44^{\mathrm{a}}$ & $-6.11^{\mathrm{a}}$ & $-6.40^{\mathrm{a}}$ & 0.003 & 2.74 \\
\hline & Stocked & $-3.41^{\mathrm{b}}$ & $-3.39^{b}$ & $-4.94^{\mathrm{a}}$ & $-5.89^{a}$ & $-5.38^{\mathrm{a}}$ & 0.001 & 2.08 \\
\hline \multirow{2}{*}{ B } & Fresh & 48.3 & 48.4 & 43.9 & 47.2 & 43.1 & 0.147 & 5.89 \\
\hline & Stocked & 49.8 & 53.0 & 56.6 & 53.7 & 50.3 & 0.095 & 6.00 \\
\hline \multirow{2}{*}{ Shell thickness } & Fresh & 0.254 & 0.255 & 0.255 & 0.254 & 0.254 & 0.954 & 0.84 \\
\hline & Stocked & 0.254 & 0.254 & 0.254 & 0.255 & 0.255 & 0.991 & 0.14 \\
\hline \multirow{2}{*}{ pH yolk } & Fresh & 5.89 & 5.90 & 6.06 & 5.89 & 5.91 & 0.204 & 3.65 \\
\hline & Stocked & 6.43 & 6.12 & 6.39 & 6.17 & 6.12 & 0.697 & 1.97 \\
\hline \multirow{2}{*}{ pH albumen } & Fresh & $8.14^{\mathrm{a}}$ & $7.81^{\mathrm{a}}$ & $7.95^{\mathrm{a}}$ & $7.65^{b}$ & $7.69^{b}$ & 0.001 & 0.85 \\
\hline & Stocked & 9.10 & 9.14 & 8.92 & 9.14 & 9.21 & 0.847 & 1.35 \\
\hline \multirow{2}{*}{ Yolk index } & Fresh & 0.446 & 0.445 & 0.403 & 0.410 & 0.455 & 0.542 & 5.79 \\
\hline & Stocked & 0.222 & 0.199 & 0.209 & 0.217 & 0.230 & 0.369 & 6.74 \\
\hline \multirow{2}{*}{ Yolk (\%) } & Fresh & $25.8^{\mathrm{ab}}$ & $24.6^{\mathrm{b}}$ & $26.0^{\mathrm{ab}}$ & $25.3^{\mathrm{ab}}$ & $27.1^{\mathrm{a}}$ & 0.050 & 2.10 \\
\hline & Stocked & 29.6 & 32.1 & 29.2 & 30.1 & 28.5 & 0.097 & 3.41 \\
\hline \multirow{2}{*}{ Albumen (\%) } & Fresh & 66.4 & 69.1 & 66.1 & 66.0 & 64.5 & 0.701 & 6.41 \\
\hline & Stocked & 60.3 & 59.4 & 61.1 & 60.7 & 61.3 & 0.658 & 5.07 \\
\hline \multirow{2}{*}{ Shell (\%) } & Fresh & 8.71 & 6.37 & 7.76 & 8.76 & 8.27 & 0.084 & 5.14 \\
\hline & Stocked & $10.0^{a}$ & $8.43^{b}$ & $9.29^{\mathrm{ab}}$ & $9.84^{\mathrm{a}}$ & $10.1^{\mathrm{a}}$ & 0.001 & 4.06 \\
\hline TBARS in the yolk (nmol & Fresh & $14.5^{\mathrm{a}}$ & $13.3^{\mathrm{ab}}$ & $10.9^{b c}$ & $11.7^{\mathrm{b}}$ & $10.4^{c}$ & 0.001 & 9.74 \\
\hline $\mathrm{MDA} / \mathrm{g})$ & Stocked & $16.7^{\mathrm{ab}}$ & $14.5^{\mathrm{ab}}$ & $11.7^{\mathrm{b}}$ & $14.8^{\mathrm{ab}}$ & $21.0^{\mathrm{a}}$ & 0.010 & 11.8 \\
\hline ACAP in & Fresh & $0.42^{b}$ & $0.49^{b}$ & $0.84^{\mathrm{a}}$ & $0.70^{\mathrm{a}}$ & 0.70 & 0.001 & 5.30 \\
\hline yolk (U.F /mg protein) & Stocked & 0.93 & 0.99 & 1.01 & 1.02 & 1.12 & 0.369 & 8.62 \\
\hline TBC in shell (x10¹ CFU) & Fresh & $378^{\mathrm{ab}}$ & $480^{\mathrm{a}}$ & $263^{b c}$ & $209^{c}$ & $313^{b}$ & 0.001 & 15.2 \\
\hline TC in the shell (x10 CFU) & Fresh & $201^{a}$ & $124^{\mathrm{b}}$ & $93.7^{c}$ & $80.4^{c}$ & $122^{\mathrm{b}}$ & 0.001 & 11.3 \\
\hline E. coli in the shell ( $\left.\times 10^{1} \mathrm{CFU}\right)$ & Fresh & $82.5^{\mathrm{a}}$ & $80.0^{\mathrm{a}}$ & $67.0^{\mathrm{b}}$ & $52.3^{c}$ & $57.2^{\mathrm{bc}}$ & 0.001 & 5.74 \\
\hline
\end{tabular}

* $P<0.05$ and different letters ( $a, b$ and $c$ ) on the same line show a significant difference between groups.

$T B C=$ total bacterial cont; $T C$ = total coliforms; . coli = Escherichia coli. Group TO birds that received a diet without propolis; group T5 birds that received 5 grams of propolis per $\mathrm{kg}$ of feed; T10 birds that received 10 grams of propolis per kg of feed; T20 birds that received 20 grams of propolis per $\mathrm{kg}$ of feed and T30 birds that received 30 grams of propolis per $\mathrm{kg}$ of feed. 
treatments $(P<0.05)$. However, for the conversion $\mathrm{kg} /$ dozen eggs, T5 and T30 were similar with a lower conversion than the other treatments ( $P$ $<0.05$ ). When measuring egg mass g/chicken/ day, T5 and T30 also showed lower results than treatments $(P<0.05$; Figure 1$)$.

\section{DISCUSSION}

The increase in specific gravity in fresh and stored eggs seems to be related to the albumen $\mathrm{pH}$ which, remained lower in treatments with $5 \mathrm{mg} / \mathrm{kg}$ and $10 \mathrm{mg} / \mathrm{kg}$ of propolis, a result not observed in other studies that used this additive (Abdel-Kareem \& El-Sheikh 2017, Belloni et al. 2015, Galal et al. 2008), similar to that observed by Dos Santos et al. (2020), who used a plant extract. This increase in gravity may have occurred due to less condensation of water through the shell's pores. The effect was natural and gradual after the egg had contact with the external environment (Dos Santos et al. 2009). In this way, the decrease in $\mathrm{pH}$ contributed. A smaller amount of hydrogen was available to carry out the condensation and water release reaction, making the air chamber remain small, which is beneficial.

In relation, the intensity of red $\left(a^{*}\right)$ the eggs of treatments T10, T20, and T30 have the highest negative values for the color yolk, in which they leave a red (positive) to a green (negative) angle. This probably occurred due to the higher dosage of green propolis in the diet, which negatively influenced the yolk red intensity.

An increase in shell thickness usually occurs by depositing minerals in this structure. Propolis increases calcium and phosphorus levels in the blood plasma and their absorption by the bark

Table III. Serum biochemistry of laying hens fed with propolis levels on days 0 and 21 of the experiment.

\begin{tabular}{|c|c|c|c|c|c|c|c|c|}
\hline Variable & Day & TO & T5 & T10 & $\mathrm{T} 20$ & T30 & P-value & CV (\%) \\
\hline \multirow{2}{*}{ Total proteins (g/dL) } & 0 & 6.20 & 6.20 & 6.70 & 6.10 & 7.05 & 0.541 & 9.74 \\
\hline & 21 & $7.60^{\mathrm{a}}$ & $4.90^{b}$ & $5.70^{b}$ & $5.8^{\mathrm{b}}$ & $5.0^{b}$ & 0.001 & 5.62 \\
\hline \multirow{2}{*}{ Triglycerides (mg/dL) } & 0 & 600 & 612 & 714 & 759 & 732 & 0.169 & 15.7 \\
\hline & 21 & $803^{\mathrm{a}}$ & $425^{b}$ & $773^{\mathrm{a}}$ & $780^{\mathrm{a}}$ & $751^{\mathrm{a}}$ & 0.001 & 18.2 \\
\hline \multirow{2}{*}{$\begin{array}{l}\text { Cholesterol } \\
(\mathrm{mg} / \mathrm{dL})\end{array}$} & 0 & 125 & 80 & 110 & 103 & 92 & 0.324 & 16.9 \\
\hline & 21 & $125^{\mathrm{ab}}$ & $88^{c}$ & $162^{\mathrm{a}}$ & $111^{b}$ & $87^{c}$ & 0.010 & 9.97 \\
\hline \multirow{2}{*}{$\begin{array}{l}\text { Uric acid } \\
(\mathrm{mg} / \mathrm{dL})\end{array}$} & 0 & 3.90 & 3.35 & 2.90 & 3.30 & 2.85 & 0.08 & 5.74 \\
\hline & 21 & 3.10 & 4.30 & 2.6 & 2.0 & 3.4 & 0.061 & 8.95 \\
\hline \multirow{2}{*}{$\begin{array}{l}\text { Albumin } \\
(\mathrm{g} / \mathrm{dL})\end{array}$} & 0 & 0.80 & 0.90 & 0.70 & 0.8 & 1.2 & 0.254 & 6.45 \\
\hline & 21 & 2.60 & 2.70 & 1.90 & 3.0 & 3.25 & 0.074 & 7.71 \\
\hline \multirow{2}{*}{ Globulins (g/dL) } & 0 & 5.40 & 5.05 & 6.0 & 6.0 & 6.2 & 0.064 & 6.78 \\
\hline & 21 & $5.50^{\mathrm{a}}$ & $4.40^{b}$ & $4.15^{b}$ & $2.45^{c}$ & $2.05^{c}$ & 0.001 & 4.06 \\
\hline
\end{tabular}

* $P<0.05$ and different letters $(a, b$ and $c$ ) on the same line show a significant difference between groups. Group T0 birds that received a diet without propolis; group T5 birds that received 5 grams of propolis per $\mathrm{kg}$ of feed; T10 birds that received 10 grams of propolis per kg of feed; T20 birds that received 20 grams of propolis per kg of feed and T30 birds that received 30 grams of propolis per $\mathrm{kg}$ of feed. 
gland (Abdel-Kareem \& El-Sheikh 2017, Seven et al. 2011). This calcium may have been directed from the bones to the shell because propolis has bone-stimulating properties (Al-Molla et al. 2014, Pereira et al. 2018).

In this study, there was a decrease in feed consumption in treatments added to propolis. Belloni et al. (2015) also observed decreased
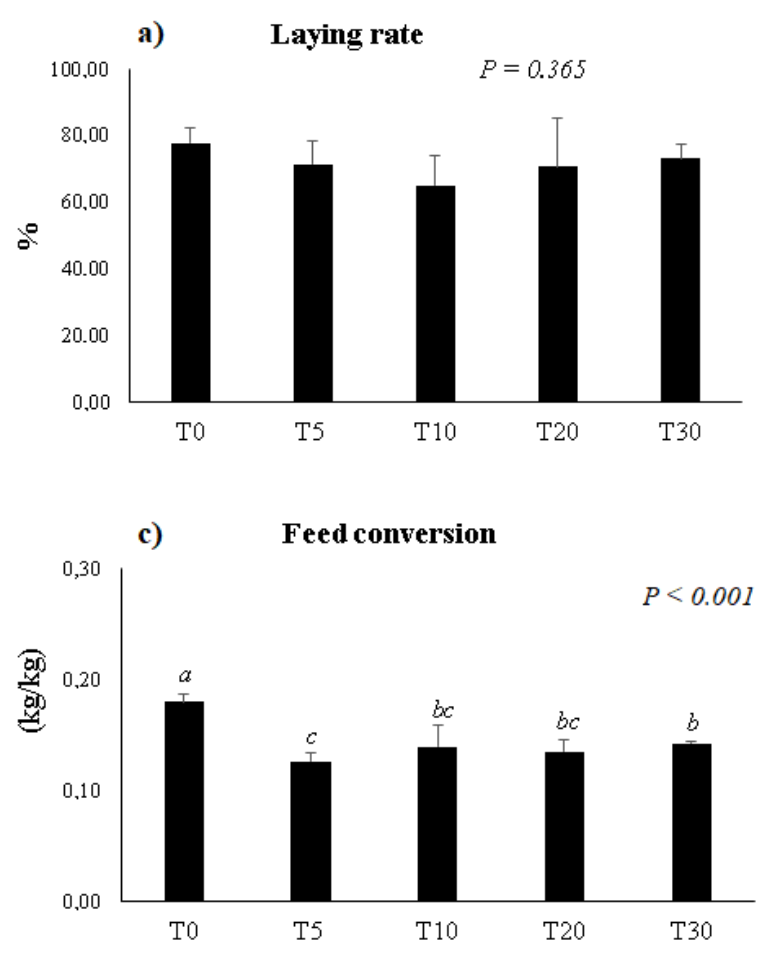

consumption when $2 \%$ and $3 \%$ of propolis were added to laying diets due to propolis's astringent flavor. Due to its antioxidant and antibacterial properties, propolis can improve the small intestine mucosa (Prakatur et al. 2019, Xue et al. 2019). Consequently, it can improve the digestion and absorption of nutrients, which explains the lower consumption and the lower
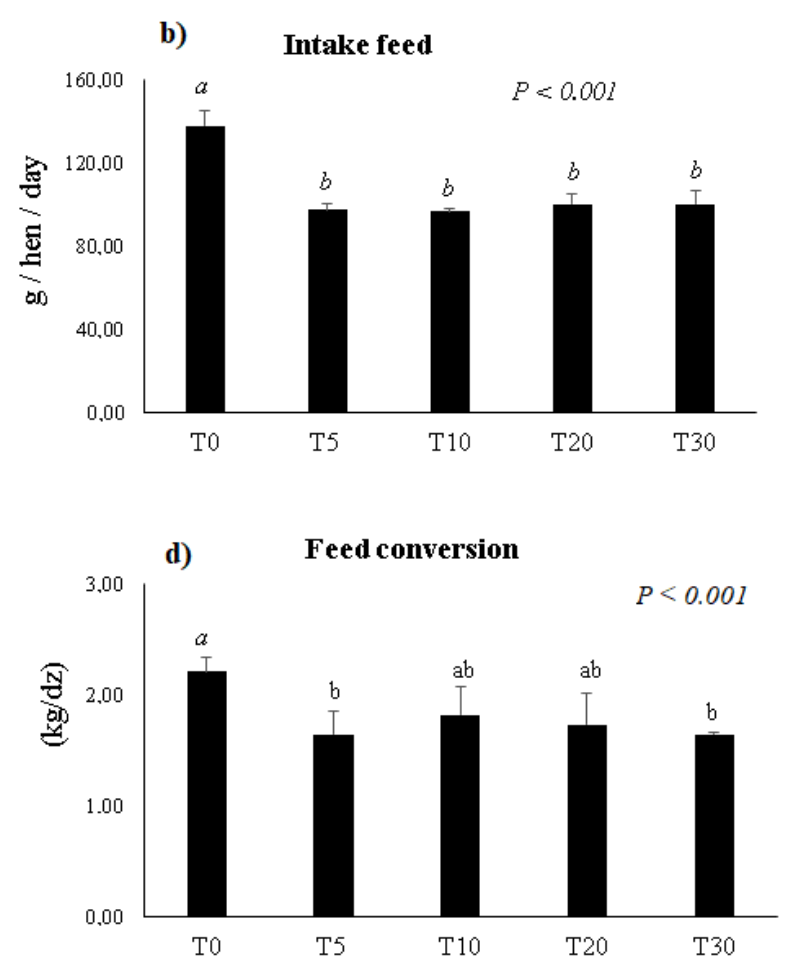

e)

Egg mass

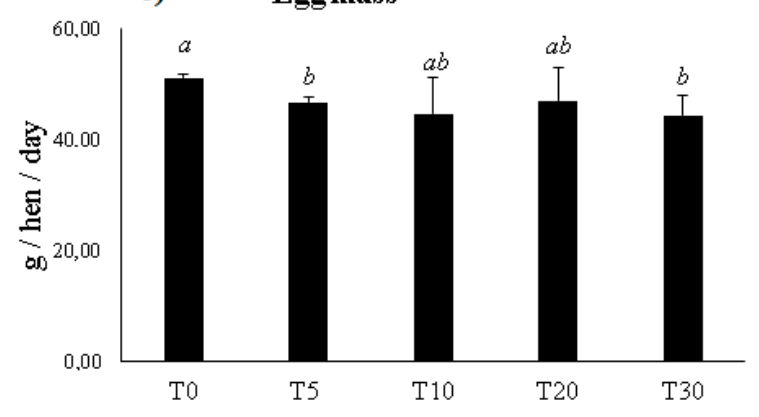

$P<0.05$

Figure 1. Productive brown Hy-line performance laying hens, 100 weeks old supplemented with increasing propolis levels: laying rate (a), intake feed (b), feed conversion - $\mathrm{kg} / \mathrm{kg}$ (c), feed conversation - $\mathrm{kg} / \mathrm{dz}$ (d), and eggs mass (e). * $P<0.05$ and different letters $(a, b$ and $c)$ on the same line show a significant difference between groups. Group T0 birds that received a diet without propolis; group T5 birds that received 5 grams of propolis per kg of feed; T10 birds that received 10 grams of propolis per $\mathrm{kg}$ of feed; T20 birds that received 20 grams of propolis per $\mathrm{kg}$ of feed and $\mathrm{T} 30$ birds that received 30 grams of propolis per $\mathrm{kg}$ of feed. 
feed conversion in T5 treatments followed by T30. However, the addition of green propolis in the dosages $5 \mathrm{mg} / \mathrm{kg}$ and $30 \mathrm{mg} / \mathrm{kg}$ reduced the egg mass, an effect that is not desirable. Belloni et al. (2015) reported that 3\% of propolis's inclusion reduced the laying rate. However, this result's explanation is still unclear due to the controversy of the benefits of adding propolis to laying birds.

The lowest level of total protein found in the birds in this research is at odds with two other studies that used propolis in a diet (AbdelKareem \& El-Sheikh 2017, Galal et al. 2008), these associated an increase in serum protein with the improvement of digestibility conferred by this additive. It is believed that the low protein that occurred in the present research was due to the immunostimulant effect of propolis observed by Nassar et al. (2012), which could stimulate the transport of amino acids for the development of defense cells and antibodies just as there was a decrease in serum globulins in supplemented treatments, which may be related to this stimulation and synthesis, since globulins are proteins that constitute antibodies.

The decrease in cholesterol in treatments T5 and T20 can be justified by stimulation of lipase or inhibition of cholesterol biosynthesis (Albokhadaim 2015), a phenomenon that is not well understood. However, Balasubashini et al. (2003) report that diabetic rats submitted to diets with ferulic acid showed lower lipid levels, and propolis has this substance in its composition. Thus, it is believed that it has decreased the expression of genes or enzymes contributing to cholesterol synthesis.

The addition of propolis at T10, T20, and T30 dosages reduced TBARS levels in fresh eggs and T10 dosage in stored eggs. These results indicate that the green propolis extract can minimize the effects of lipid peroxidation. T10, T20, and T30 increased antioxidant capacity biomarker (ACAP) levels in the yolk. Therefore, the propolis extract may have transferred its antioxidant compounds directly or indirectly. Thus, a possible action mechanism may be due to flavonoid compounds, phenolic acid (Khan 2017), and terpenoids (Arslan \& Seven 2017). In this way, these compounds with antioxidant properties prevent or reduce the formation of free radicals such as hydrogen peroxide, which cause cellular and tissue damage. These antioxidant compounds act by donating their hydroxyl groups and, thereby, reduce malonaldehyde levels since TBARS levels have been reduced (Botsoglou et al. 2005), as seen in the present study.

Lipid peroxidation is an undesirable factor in food, as it can cause a rancid taste and, in this way, reduces the sensory and nutritional quality of eggs (Olmedo et al. 2014). Haščik et al. (2014) report that propolis's addition decreased malonaldehyde levels in broiler meat due to its antioxidant activity compounds. Thus, propolis extract's addition had a positive effect on the internal quality of eggs by reducing lipid peroxidation and, thus, maintaining the sensory and nutritional quality of fresh eggs stored at room temperature.

The decrease in the total bacterial count, coliforms, and E. coli at T10 and T20 dosages is mainly associated with the antibacterial properties of propolis (Shehata et al. 2020) that work through chemical compounds and the inhibition of the bacterium's RNA polymerase enzyme, which compromises protein transcription and synthesis (Almuhayawi 2020). This occurs due to the permeability of the bacterial membrane, which, through the cinnamic acid and benzoic acid present in the propolis composition, acidifies the medium affecting the cell homeostasis, ATP production, and biofilm (Almuhayawi 2020, Yilmaz et al. 2018). 


\section{CONCLUSION}

Therefore, it is concluded that the addition of green propolis in dosages 10 and $20 \mathrm{mg} / \mathrm{kg}$ was able to reduce the total bacterial count and E. coli in the eggshells. Also, it reduced peroxidation, oxidation and increased the antioxidant capacity of eggs. However, these dosages reduced the egg mass, an undesirable effect for the laying poultry chain. Further studies are needed to find an ideal dosage to maintain or improve animal performance in this context.

\section{Acknowledgments}

We thank Fundação de Amparo à Pesquisa e Inovação do Estado de Santa Catarina (FAPESC), Coordenação de Aperfeiçoamento de Pessoal de Nivel Superior (CAPES), and Conselho Nacional de Desenvolvimento Científico e Tecnológico (CNPq) for their technical support.

\section{REFERENCES}

ABDEL-KAREEM AAA \& EL-SHEIKH TM. 2017. Impact of supplementing diets with propolis on productive performance, egg quality traits and some haematological variables of laying hens. J Anim Physiol Anim Nutr 101(3): 441-448.

ABPA - ASSOCIAÇÃO BRASILEIRA DE PROTEÍNA ANIMAL. 2019. Relatório Anual ABPA 2019. Disponível em:<http:// https://abpa-br.org/relatorios/ >. Acesso em: $21 \mathrm{dez}$ 2020.

ABPA - ASSOCIAÇÃO BRASILEIRA DE PROTEÍNA ANIMAL. 2020. Relatório Anual ABPA 2020. Disponível em:<http:// cleandrodias.com.br/wp-content/uploads/2019/05/ RELATO\%C3\%ACRIO-ANUAL-ABPA-2019.pdf>. Acesso em: 21 dez 2020.

ALBOKHADAIM I. 2015. Influence of dietary supplementation of propolis on hematology, biochemistry and lipid profile of rats fed high cholesterol diet. J Adv Vet Animal Res 2(1): 56-63.

AL-MOLLA, AL-GHABAN N \& TAHER A. 2014. Immunohistochemical evaluation: The effects of propolis on osseointegration of dental implants in rabbit's tibia. Int J Dent Res Rev 1(3): 123.

ALMUHAYAWI MS. 2020. Propolis as a novel antibacterial agent. Saudi J Biol Sci 27(11): 3079-3086.
ARSLAN AS \& SEVEN PT. 2017. The effects of propolis on serum malondialdehyde, fatty acids and some blood parameters in Japanese quail (Coturnix coturnix japonica) under high stocking density. J Appl Anim Res 45: 417-422.

BALASUBASHINI MS, RUKKUMANI R \& MENON VP. 2003. Protective effects of ferulic acid on hyperlipidemic diabetic rats. Acta Diabetol 40(3): 118-122.

BELLONI M, ALMEIDA PAZ ICL, NÄÄS IA, ALVES MCF, GARCIA RG, CALDARA FR \& SENO L. 2015. O. Productive, qualitative, and physiological aspects of layer hens fed with propolis. Rev Bras Cienc Avic 17(4): 467-472.

BOTSOGLOU N, FLOROU-PANERI P, BOTSOGLOU E, DOTAS $V$, GIANNENAS I, KOIDIS A \& MITRAKOS P. 2005. The effect of feeding rosemary, oregano, saffron and a-tocopheryl acetate on hen performance and oxidative stability of eggs. S Afr J Anim Sci 35(3).

CARDOZO RM, BARBOSA MJB, PONTARA L \& SOUZA VLF. 2013. Efeito da própolis no estímulo do sistema imunológico de frangos de corte. Revista Cultivando o Saber 6(2): 7-13.

CECERE B, DA SILVA AS, MOLOSSE VL, ALBA DF, LEAL KW, DA ROSA G, PEREIRA WA, DA SILVA AD, SCHETINGER MRC, KEMPKA AP, NUNES A, MARASCHIN M, ARAÚJO DN, DEOLINDO GL \& VEDOVATO M. 2021. Addition of propolis to milk improves lactating lamb's growth: Effect on antimicrobial, antioxidant and immune responses in animals. Small Rumin Res 194: 106265.

DING X, YU Y, SU Z \& ZHANG K. 2017. Effects of essential oils on performance, egg quality, nutrient digestibility and yolk fatty acid profile in laying hens. Anim Nutr 3(2): 127-131.

DOS SANTOS AFA, DA SILVA AS, GALLI GM, PAGLIA EB, DACOREGGIO MV, KEMPKA AP, SOUZA CF, BALDISSERA MD, DA ROSA G, BOIAGO MM \& PAIANO D. 2020. Addition of yellow strawberry guava leaf extract in the diet of laying hens had antimicrobial and antioxidant effect capable of improving egg quality. Biocatal Agric Biotechnol 29: 101788.

DOS SANTOS MSV, ESPÍNDOLA GB, LÔBO RNB, FREITAS ER, GUERRA JLL \& SANTOS ABE. 2009. Effect of temperature and storage of eggs. Food Sci Tecnol 29(3): 513-517.

EREL O. 2004. Um novo método de medição direta automatizado para capacidade antioxidante total usando uma nova geração, cátion radical ABTS mais estável. Biochim Clin 37(4): 277-285.

FREITAS ER, SAKOMURA NK, GONZALEZ MM \& BARBOSA NAA. 2004. Notas Científicas. Comparação de métodos de determinação da gravidade específica de ovos de poedeiras comerciais. Pesq Agropec Bras 39: 509-512. 
GALAL A, ABD EL-MOTAAL AM, AHMED AMH \& ZAKI TG. 2008. Productive Performance and Immune Response of Laying Hens as Affected by Dietary Propolis Supplementation. Int J Poult Sci 7(3): 72-278.

GANTOIS I, DUCATELLE R, PASMANS F, HAESEBROUCK F, GAST R, HUMPHREY TJ \& VAN IMMERSEEL F. 2009. Mechanisms of egg contamination by Salmonella Enteritidis: FEMS Microbiol Rev 33(4): 718-738.

GARCÉS, TAM, HERRERA AL \& SUESCÚN JEP. 2018. Efecto del aceite esencial de orégano (Lippia origanoides) sobre metabolitos sanguíneos en pollos de engorde. Rev Bras Med Vet 37: 25-33.

GAST RK, GURAYA R \& GUARD J. 2013. Salmonella enteritidis deposition in eggs after experimental infection of laying hens with different oral doses. J Food Prot 76(1): 108-113.

GENOVA JL, RODRIGUES RB, MARTINS JS, UCZAY M \& HENRIQUES JKS. 2020. Própolis e pólen apícola na nutrição de animais não ruminantes. Arch de Zootec 69(265): 124-131.

GIAMPIETRO A, SCATOLINI AM, BOIAGO MM, CORÓ DMO, SOUZA HBA, SOUZA PA, LIMA TMA \& PIZZOLANTE CC. 2008. Estudo da metodologia de tbars em ovos. Unesp, São Paulo.

HAUGH RR. 1937. A new method for determining the quality of an egg. US Egg Poult 39: 27-49.

HAŠČIK P, GARLIK J, ELIMAM IOE, KŇAZOVICKA V, BOBKO M \& KAČANIOVA M. 2014. Influence of propolis extract in Hubbard JV chickens nutrition on oxidative stability of meat. Acta Fytotech Zootech 17(2): 47-51.

KHAN SH. 2017. Recent Advances in Role of Propolis as Natural Additive in Poultry Nutrition. J Apic Sci 61(2): 167-183.

MENDONÇA THC, SOARES ARS, DA SILVA JR, SOUZA MS \& DA SILVA RG. 2019. Padronização e qualidade de ovos caipiras comercializados em feira livre no município de Vitória de Santo Antão (Pernambuco-Brasil). RVBMA 7(3).

NASSAR SA, MOHAMED AH, SOUFY H, NASR SM \& MAHRAN KM. 2012. Immunostimulant effect of Egyptian propolis in rabbits. Sci World J 2012: 901516.

OLMEDO R, NEPOTE V \& GROSSO NR. 2014. Antioxidant activity of fractions from oregano essential oils obtained by molecular distillation. Food Chem 156: 212-219.

PARISI MA, NORTHCUTT JK, SMITH DP, STEINBERG EL \& DAWSON PL. 2015. Microbiological contamination of Shell eggs produced in conventional and free-range housing systems. Food Control 47: 161-165.

PEREIRA YCL, ISSA JPM, WATANABE E, NASCIMENTO GC, IYOMASA MM \& ERVOLINO E. 2018. The Therapeutic Use of Propolis
Extract in Alveolar Bone Contaminated with Bacterial Endotoxin. Dentistry 8: 473.

PRAKATUR I, MISKULIN M, PAVIC M, MARJANOVIC K, BLAZICEVIC V, MISKULIN I \& DOMACINOVIC M. 2019. Morphology in broiler chickens supplemented with propolis and bee pollen. Animals 9: 301.

PROCÓPIO DP \& LIMA HJD. 2020. Poultry production conjecture in Brazil. Res Soc Dev 9(3).

ROSTAGNO HS, ALBINO LFT, DONZELE JL, GOMES PC, DE OLIVEIRA RF, LOPES DC, FERREIRA AS \& BARRETO SLT. 2017. Composição de alimentos e exigências nutricionais. Tabelas brasileiras para aves e suínos, Viçosa. Minas Gerais, Brazil: Universidade Federal de Viçosa.

SANTOS ÉC DOS, TEIXEIRA AS, FREITAS RTF DE, RODRIGUES PB, DIAS ES \& MURGAS LDS. 2005. Uso de aditivos promotores de crescimento sobre o desempenho, características de carcaça e bactérias totais do intestino de frangos de corte. Ciênc e Agrotecnologia 29(1): 223-231.

SEVEN I, TATPLI SEVEN P \& SILICI S. 2011. Effects of dietary Turkish propolis as alternative to antibiotic on growth and laying performances, nutrient digestibility and egg quality in laying hens under heat stress. Rev Méd Vét 162(4): 186-191.

SHEHATA MG, AHMAD FT, BADR AN, MASRY SH \& EL-SOHAIMY SA. 2020. Chemical analysis, antioxidant, cytotoxic and antimicrobial properties of propolis from different geographic regions. Ann Agric Sci 65: 209-217.

VALENTIM JK, RODRIGUES RFM, BITTENCOURT TM, LIMA HJD \& RESENDE GA. 2018. Implicações sobre o uso de promotores de crescimento na dieta de frangos de corte. NutriTime 15(14): 1-9.

XUE M, LIU Y, XU H, ZHOU Z, MA Y, SUN T, LIU M, ZHANG H \& LIANG H. 2019. Propolis modulates the gut microbiota and improves the intestinal mucosal barrier function in diabetic rats. Biomed Pharmacother 118: 109393.

YILMAZ S, SOVA M \& ERGÜN S. 2018. Antimicrobial activity of trans -cinnamic acid and commonly used antibiotics against important fish pathogens and nonpathogenic isolates. J Appl Microbiol 125(6): 1714-1727.

ZHU YW, XIE JJ, LI WX, LU L, ZHANG Y, JI C, LIN X, LIU HC, ODLE J \& LUO XG. 2015. Effects of environmental temperature and dietary manganese on egg production performance, egg quality, and some plasma biochemical traits of broiler breeders. Sci J Anim 93: 3431-3440. 


\section{How to cite}

CASAGRANDE AC, MACHADO GC, BRUNETTO AL, GALLI GM, DA ROSA G, ARAUJO DN, BOIAGO MM, SOUZA CF, BALDISSERA MM \& DA SILVA AS. 2021. The addition of green propolis to laying hens had positive effects on egg quality: lower bacteria counts in the shell and lipid peroxidation in the yolk. An Acad Bras Cienc 93: e20210315. DOI 10.1590/0001-3765 202120210315.

Manuscript received on February 28, 2021; accepted for publication on August 9, 2021

\section{ANA CLAUDIA CASAGRANDE ${ }^{1}$}

https://orcid.org/0000-0002-2060-4149

\section{GIOVANA C. MACHADO}

https://orcid.org/0000-0002-9468-8285

\section{ANDREI L. BRUNETTO 1}

https://orcid.org/0000-0001-5970-7703

GABRIELA M. GALLI ${ }^{2}$

https://orcid.org/0000-0001-6734-8659

\section{GILNEIA DA ROSA ${ }^{2}$}

https://orcid.org/0000-0003-0412-4919

DENISE N. ARAUJO',

https://orcid.org/0000-0001-9606-5447

MARCEL M. BOIAGO ${ }^{1,2}$

https://orcid.org/0000-0002-0950-4577

CARINE F. SOUZA 3

https://orcid.org/0000-0001-9978-0454

MATHEUS M. BALDISSERA ${ }^{3}$ https://orcid.org/0000-0002-3280-8528

ALEKSANDRO S. DA SILVA ${ }^{1,2}$

https://orcid.org/0000-0002-9860-1933

${ }^{1}$ Universidade do Estado de Santa Catarina (UDESC),

Departamento de Zootecnia, Rua Beloni Trombeta Zanin, 680E - Zootecnia, 89815-630 Chapecó, SC, Brazil

${ }^{2}$ Programa de Pós-Graduação em Zootecnia,

UDESC, Rua Beloni Trombeta Zanin, 680E -

Zootecnia, 89815-630 Chapecó, SC, Brazil

${ }^{3}$ Universidade Federal de Santa Maria (UFSM),

Departamento de Fisiologia e Farmacologia, Av. Roraima,

1000, Camobi, 97105-900 Santa Maria, RS, Brazil

Correspondence to: Aleksandro S. Da Silva

E-mail:dasilva.aleksandro@gmail.com

\section{Author contributions}

Araujo DN, Boiago MM and Da Silva AS: contributed to the design and implementation of the research, to the analysis of the results. Casagrande AC, Machado GC, Brunetto AL and Galli GM: participated in the execution of the experiment and collection of samples and data. Souza CF, Baldissera MD and Rosa G did the laboratory analysis. All authors discussed the results and contributed to the final manuscript.

\section{(cc) BY}

